CURRENT RESEARCH JOURNAL OF HISTORY 2(5): 54-58, May 2021

DOI: https://doi.org/10.37547/history-crjh-02-05-14

ISSN 2767-472X

(C)2021 Master Journals

3 Crossref dot 81 Google

Accepted 25th May, 2021 \& Published 31 th May, 2021

\title{
GATHERING BY DIVESTITURE AND EXTREMISM IN DISSEMINATION IN INDIA: ROLE OF THE STATE
}

\section{Frank N.L.}

Department Of History, University Of The Cordilleras, Philippines

\section{ABSTRACT}

Divestiture and constrained partition of a segment of individuals from the methods for creation are inseparably connected with state-drove financial turn of events. In an acquired post-frontier improvement worldview, a 'big picture perspective' continued in India barred individuals living at the lower part of the financial stepping stool as equivalent accomplices who regarding rising 'standard' material assumptions experience 'divestiture' by removal. Extremism dependent on this ground reality, an outcome of lopsided improvement across friendly and monetary classes and across locales, turns into a result that worries both the state and the common society. Maybe than pulling out from the framework that advanced and got broken over the long haul, the paper thinks, the state needs to assume a critical part being developed the start and base of which must be to take into certainty the minimized areas of the general public like the ancestral individuals, the discouraged, and the poor as noble and equivalent accomplices.

KEYWORDS: - Gathering, Divestiture, Radicalism, State.

\section{INTRODUCTION}

Advancement turned into the catchphrase for the social researchers maybe since the times of

Adam Smith. The state caught 'improvement' to 
CURRENT RESEARCH JOURNAL OF HISTORY 2(5): 54-58, May 2021

DOI: https://doi.org/10.37547/history-crjh-02-05-14

ISSN 2767-472X

(C)2021 Master Journals

Crossref doi 81 Google

Accepted 25 $5^{\text {th }}$ May, $2021 \&$ Published 31 $1^{\text {th }}$ May, 2021

manage it, give it an importance, since

advancement is widely inclusive and entrancing;

the state turned into the overseer or underwriter

of advancement maybe since the Great

Depression (1929-1933). The state as the

defender of residents proclaimed itself as the specialist of improvement and got caught with different complexities in a worldwide setting. In any event, when the worldwide organizations and foundations characterize advancement, the state either acknowledges or dismisses that characterized way remembering the prevailing state that played the critical part for such definition - this is a result of the states being common partners of the predominant state. The political-philosophical point of view being developed along these lines can't be escaped. At the public level, the state needed to detail rules and laws for molding creation, including individuals. From free development of individuals for exchange across the globe preceding European control of the world economy, it turned out to be free development of capital alongside confined development of individuals across nations post-arrangement of European states. Advancement post-Keynes is principally seen as a result of venture, and consequently the significance of producing reinvestible excess. Amassing turns into the precondition for improvement. Capital proprietors and regulators can't do it single-handedly growing the degree and space to re-produce capital through its dissemination. Subsequently, the job of recreating work came to re-make the space for course of capital and expanding aggregation. Both public and transnational capital required wellbeing that must be ensured by the state and thus the job of the states in worldwide financial relations got conspicuous.

\section{Methods}


CURRENT RESEARCH JOURNAL OF HISTORY 2(5): 54-58, May 2021

DOI: https://doi.org/10.37547/history-crjh-02-05-14

ISSN 2767-472X

(C)2021 Master Journals

Crossref dof 81 Google

Accepted 25th May, 2021 \& Published 31 th May, 2021

There are some immediate strategies for private amassing like plunder and loot, abuse of the oblivious individuals in the casual rustic credit market, move of land proprietorship by trickery, keeping between generational work reinforced and restricted, essentially liberated from cost youngster work and so forth There are likewise backhanded methods of gathering like exchange or channel of assets starting with one country then onto the next through political colonization, addition, monetary incomparability by profession related inconsistent trade, manipulative valuing in an intra-firm trade across borders, bargain of advantages inside and across nations. In a post-private property situation in a specific economy, the individual can apply higher intellectual prowess to deny others to snatch the land regions and resources underground. Change of assets without anyone else work and employed work as the subsidiary of this prompts items showing worth of a sort not quite the same as what the nature straightforwardly gives. In post-government, the assets have a place with individuals where the state turns into the caretaker of assets. For the state, gathering for upgrade of state power by limit of creation to begin with relies upon how best to use the populace as laborers to produce excess. The natural limit of the person as a specialist in the space of creation hence turns into the foundation of amassing by assignment of the excess worth that the laborer produces.

\section{Conclusion}

The issue of extremism in this manner isn't one of the rule of law, as is frequently perceived by the state - it is established in rejection and hardship of individuals from the cycles and advantages of improvement. It additionally could be that the state is prepared to acknowledge the credulous adaptation of the repetitive 
CURRENT RESEARCH JOURNAL OF HISTORY 2(5): 54-58, May 2021

DOI: https://doi.org/10.37547/history-crjh-02-05-14

ISSN 2767-472X

(C)2021 Master Journals

Crossief do) 88 Google

Accepted 25th May, 2021 \& Published 31 th May, 2021

emergencies. State plans transient measures to

\section{REFERENCES}

resolve the noticeable issues and offers an

answer as a restorative change. It is regularly in

light of the fact that the Government is chosen for

a most extreme time of five years past which its

destiny is obscure. Frequently the offered

arrangements change ordinarily and

classification. The arrangement of neediness

easing projects and plans bear declaration to

this. The administrative state isn't befuddled on

the thing it is offering - it confounds individuals

at the base. The state soundly contends for

1. Bagchi, Amiya, K, 1989, 'Uprooting and

Rehabilitation - An Estimate of Extent and

Prospects', Indian Social Institute, New

Delhi.

2. Banerjee, Sumanta., 1962, 'The

Diversionists', The Economic Weekly, July

1.

harmony and solidness without understanding

that divestiture at the base layer of the general

public is conflicting with such 'tranquility of the

cemetery'. Notwithstanding, the state apparatus

3. Bhattacharya, Buddhadeb. (Ed.), 1999, International Encyclopedia of Economics, Vol. I and II, London.

feels good to comprehend the issue as one of the rule of law. However, at that point it regularly neglects to set the suitable viewpoint of law and order for social change combining to a libertarian culture

5. Majumder, Bhaskar, 2001, 'Cross-line 
CURRENT RESEARCH JOURNAL OF HISTORY 2(5): 54-58, May 2021

DOI: https://doi.org/10.37547/history-crjh-02-05-14

ISSN 2767-472X

(C)2021 Master Journals

Crossref doi) 81 Google

Accepted 25 $5^{\text {th }}$ May, 2021 \& Published 31 ${ }^{\text {th }}$ May, 2021

Movements of People', in Nayyar, Deepak

(Ed.), 'Administering Globalization, Issues

and Institutions', Oxford Univ. Press, New

Delhi. 